\title{
ASSESSMENT OF THE TDCS INFLUENCE ON STRESS-INDUCED DISORDERS IN RATS WITH LOW STRESS SUSTAINABILITY AND ENDURANCE
}

Aksinia Lipatova ${ }^{1}$, Azamat Kade ${ }^{1}$, Artem Trofimenko ${ }^{1}$, Viktor Ovsiannikov ${ }^{2}$, Oleg Tcymbalov ${ }^{1}$ and Aleksandr Sidorenko ${ }^{1}$ Department of Common and Clinical Pathophysiology, Kuban State Medical University, Krasnodar, Russia ${ }^{2}$ Department of Pathophysiology, Rostov State Medical University, Rostov-on-Don, Russia

\section{ISPITIVANJE UTICAJA TDCS-A NA STRESOM IZAZVANE POREMEĆAJE KOD PACOVA SA NISKOM TOLERANCIJOM NA STRES Aksinia Lipatova $^{1}$, Azamat Kade ${ }^{1}$, Artem Trofimenko ${ }^{1}$, Viktor Ovsiannikov², Oleg Tcymbalov ${ }^{1}$ i Aleksandr Sidorenkd ${ }^{1}$ Katedra za opštu i kliničku patofiziologiju, Medicinski državni univerzitet u Kubanu, Krasnodar, Rusija ${ }^{2}$ Katedra za patofiziologiju, Medicinski državni univerzitet u Rostovu, Rostov na Donu, Rusija}

\begin{abstract}
The aim of study is to analyze the tDCS influence on stressinduced disorders in rats with low stress sustainability and endurance. The animals with a low stress sustainability and endurance were divided into 3 groups: the comparison 1, the comparison 2 and the main. The control group consisted of intact rats. The rats of the comparison group 1 were subjected to orthostatic stress 24 hours after the 1st forced swimming test. The rats of the comparison group 2 and the main one were conducted the 2nd forced swimming test on the 7th day of the experiment, and 24 hours later they were subjected to the orthostatic stress. Rats of the main group got tDCS sessions after the 1st forced swimming test. The development of the orthostatic stress is accompanied by an increase in plasma content the following components: adrenaline by $88.9 \%$, ACTH in 10.5 times, corticosterone by $70.1 \%, I L-1 \beta$ by $178.2 \%$, IL-6 in 6.7 times, IL-10 by $37.1 \%$ in comparison with intact animals. The usage of $t D C S$ in rats with low stress sustainability and endurance increased the swimming duration by $47.7 \%$. During the OS it was also accompanied by a decrease in plasma content: adrenaline in 1.4 times, ACTH in 8.2 times, corticosterone in 1.4 times, IL-1 $\beta$ in 1.5 times, IL-6 in 2.2 times, IL-10 in 1.2 times, relative to the comparison group 2 . The obtained data showed the essential effect of tDCS on stress-related changes in the content of cytokines and hormones of blood.
\end{abstract}

Keywords: stress, $t D C S$, rat, cytokines, corticosterone

\section{SAŽETAK}

Cilj studije je da analizira uticaj tDCS na stresom izazvane poremećaje kod pacova sa niskom tolerancijom na stres. Životinje su bile svrstane u tri grupe: poredbena grupa 1 , poredbena grupa 2 i glavna grupa. Kontrola grupa se sastojala od zdravih pacova. Pacovi iz poredbene grupe 1 su bili podvrgnuti ortostatskom stresu 24 sata nakon prvog testa forsiranog plivanja. Pacovi iz poredbene grupe $2 i$ iz glavne grupe su bili podvrgnuti 2. forsiranom testu plivanja 7. dana eskperimenta dok su 24 sata kasnije bili izloženi ortostatskom stresu. Pacovi iz glavne grupe su bili podvrgnuti tDCS sesiji nakon prvog testa forsiranog plivanja. Ortostatski stres je bio praćen povećanom koncentracijom sledećih komponenti plazme: adrenalina za 88,9\%, ACTH za 10.5 puta, kortikosterona za 70,1\%, IL-1b za 178,2\%, IL-6 za 6,7 puta, IL-10 za 37,1\% u poređenju sa zdravim životinjama. Korišćenje tDCS-a kod pacova je produžilo trajanje plivanja za 47,7\%. Ortostatski stress je bio praćen smanjenjem plazma koncnetracije: adrenalina za 1,4 puta, ACTH za 8.2 puta, kortikosterona za 1,4 puta, IL-1b za 1,5 puta, IL-6 za 2,2 puta, IL-10 za 1,2 puta, u odnosu na grupu poređenja 2. Dobijeni podaci pokazuju značajni efekat tDCS-a na stresom izazvane promene u sadržaju citokina $i$ hormona u krvi.

Ključne reči: stres, tDCS, pacov, citokini, kortikosteron 


\section{INTRODUCTION}

Stress is the organism's reply to various cognitive, emotional and somatic stressors, which realizes through the activation of a unified neuroimmune endocrine system and consists in the activation of a number of physiological and behavioral programs that facilitate survival $(1,2)$.

Stress-related changes in the functioning of sympathoadrenal (SAS), hypothalamic-pituitary-adrenal (GPAS) and immune systems are connected not only with the adaptation of the organism to new life conditions, but also with the risk of developing a variety of stress-associated diseases (3). In this case, the activation of non-specific inflammation takes a specific part in the development of adverse stress manifestations, which in particular reveals by an increase in the level of either pro-inflammatory or anti-inflammatory cytokines (4).

It is known that organisms with different coping strategies react differently to stressors and that this fact determines the stress outcome (5). In these circumstances, studying of the reaction to the stressor in animals with different stress sustainability turns into a theme of the especial interest. It opens the way to find methods for correcting stress sustainability and endurance in people who have active and passive coping strategies.

Opioid peptides take a significant function in controlling the growth of the stress reaction. The greatest amount of them is released in hypothalamus, pituitary and limbic structures of the brain during the pain or stress processes, as well as intense physical exercises $(6,7)$. The stress-limiting effect of opioid peptides is mediated by the activation of $\mu$ - and $\delta$-opioid receptors, for which $\beta$-endorphin demonstrates high selectivity $(7,8)$.

The $\beta$-endorphin emitted during the stress growth mediates endocrine and behavioral reactions, aimed at adapting the organism to extreme conditions and conduces to restricting adverse effects of stress $(9,10)$. $\beta$-endorphin stimulates the reward system, inhibits the activity of the GPAS, reduces the level of corticotropin-releasing hormone and adrenocorticotropic hormone (ACTH), and suppress pain and anxiety as well $(7,11)$.

In connection with the expressed stress-limiting effect of opioid peptides, the research of methods which can stimulate the endogenous opioidergic system activity is an important task of modern medicine.

Transcranial direct current stimulation (cathodic tDCS or TES-therapy by Professor Lebedev) is a physiotherapeutic non-invasive method of electrical impact on the brain of humans and animals through the cranium tegument, selectively activating the defense mechanisms of the brain. Its main effects are due to the increased production of $\beta$-endorphin and the concomitant changes in the production of other neurotransmitters: dopamine, norepinephrine, serotonin, GABA and others $(12,13)$.

The main objective of this study was to explore the effectiveness of cathodic tDCS for correcting stress-induced disorders of hormonal and cytokine profile in rats with low stress sustainability and endurance.

\section{MATERIAL AND METHODS}

\section{Characteristic of experimental animals}

Experiments were performed on 182 males of white nonlinear rats weighing $195 \pm 15 \mathrm{~g}$, which had no visible signs of disease. The animals were kept on a vivarium at a temperature of $22-24^{\circ} \mathrm{C}$ under the conditions of 5 animals in a cage, a 12/12 cycle of daylight in plastic cages with wood filings and free access to food (standard nutrition) and water. Such conditions excluded the impact of stress factors. The criteria for elimination from the experiment were external anatomical defects and signs of disease.

All experiments were carried out in accordance with the international rules of "Guide for the Care and Use of Laboratory Animals” (NAP, 2012).

\section{The design of studying}

At the beginning of the experiment the endurance and stress sustainability of animals were assessed with the help of the forced swimming test (FST) in the modification of the Federal Medical and Biological Agency of Russia (14). Rats with low stress sustainability and a swimming time not exceeding 184 seconds $(n=43)$ were selected in the research. Then the animals were divided into 3 groups: the comparison group $1(\mathrm{n}=10)$, the comparison group $2(n=16)$ and the main group $(\mathrm{n}=17)$. Intact rats $(\mathrm{n}=10)$ selected from the general population using the random number method were used as control ones. The rats of the comparison group 1 were subjected to the orthostatic stress (OS) 24 hours after the 1st FST (on the 2nd day of the experiment), for which they were placed in the anti-orthostatic position at an angle of $90^{\circ}$ to the horizontal surface in plexiglas fixators with a size of $210 \times 65 \times 65 \mathrm{~mm}$ (RPC Open Science Ltd.) for 45 minutes (15). The rats of the comparison group 2 and the main group were performed in the second FST on the 7th day of the experiment, and 24 hours later (on the 8 th day of the experiment) they were subjected to the OS. Meanwhile, rats of the main group got one session of cathodic tDCS per day for 5 days after the 1st FST (from the 2nd to the 6th days) using a two-program electric stimulator “TRANSAIR-03” (TES CENTER Ltd., St. Petersburg) by the method in our own modification (16).

The rat's blood was sampled before the OS and 2 hours later it by the venepunction of jugular veins under the combined injection anesthesia: Zoletil $20 \mathrm{mg} / \mathrm{kg}$ IM (Virbac, France) and Xylanite $6 \mathrm{mg} / \mathrm{kg}$ IM (NITA-FARM CJST, Russia). Heparin (BELMEDPREPARATY RUE, Belarus) was used as an anticoagulant at a rate of 500 units per $1 \mathrm{ml}$ of blood. Then the blood was centrifuged for 15 minutes at the acceleration of $1000 \mathrm{~g}$. Samples of the received plasma were stored in cryovials at a temperature of $-80^{\circ} \mathrm{C}$ (Figure 1 ). 
Table 1. The duration of swimming in rats with low stress sustainability and endurance in the forced swimming test on the 1 st and the 7 th days

\begin{tabular}{|l|c|c|c|}
\hline \multicolumn{1}{|c|}{ Group } & $\begin{array}{c}\text { The duration swimming of the } \\
\text { 1st FST, } \\
\text { Me }\left(\mathbf{Q}_{1}-\mathbf{Q}_{3}\right) \text {, sec. }\end{array}$ & $\begin{array}{c}\text { The duration swimming of the } \\
\text { 2nd FST, } \\
\text { Me }\left(\mathbf{Q}_{1}-\mathbf{Q}_{3}\right) \text {, sec. }\end{array}$ & $\begin{array}{c}\text { p-value } \\
\text { (W-test) }\end{array}$ \\
\hline The comparison 2 & $161,5(146,5-171,5)$ & $166,5(160-215,5)$ & 0,05 \\
\hline The main & $151(122-166)$ & $223(168-274)$ & 0,001 \\
\hline
\end{tabular}

\section{The method of enzyme-linked immunosorbent assay}

Quantitative evaluation of the adrenaline and adrenocorticotropic hormone levels in plasma was realized by the method of enzyme-linked immunosorbent assay using Cloud-Clone Corp. (China) kits. Corticosterone level was evaluated by Immunodiagnostic Systems Limited (UK). IL-1 $\beta$, IL- 6 and IL-10 levels were evaluated by eBioscience (Bender MedSystems GmbH, Austria) using the vertical scanning photometer ANTHOS 2010 (Biochrom, Austria) with ADAP Software, version 2.0.

\section{Statistical analysis}

Statistical data analysis was carried out with the help of the software "MS Excel 2016" (Microsoft, the USA) and "Statistica 10.0" (StatSoft Inc., the USA). Verification of the normality of the quantitative attributes distribution in experimental groups was carried out using the Shapiro-Wilk test. Since the distribution of meanings differed from the normal one, nonparametric statistics were used for further research data processing. The results were expressed as $\mathrm{Me}$

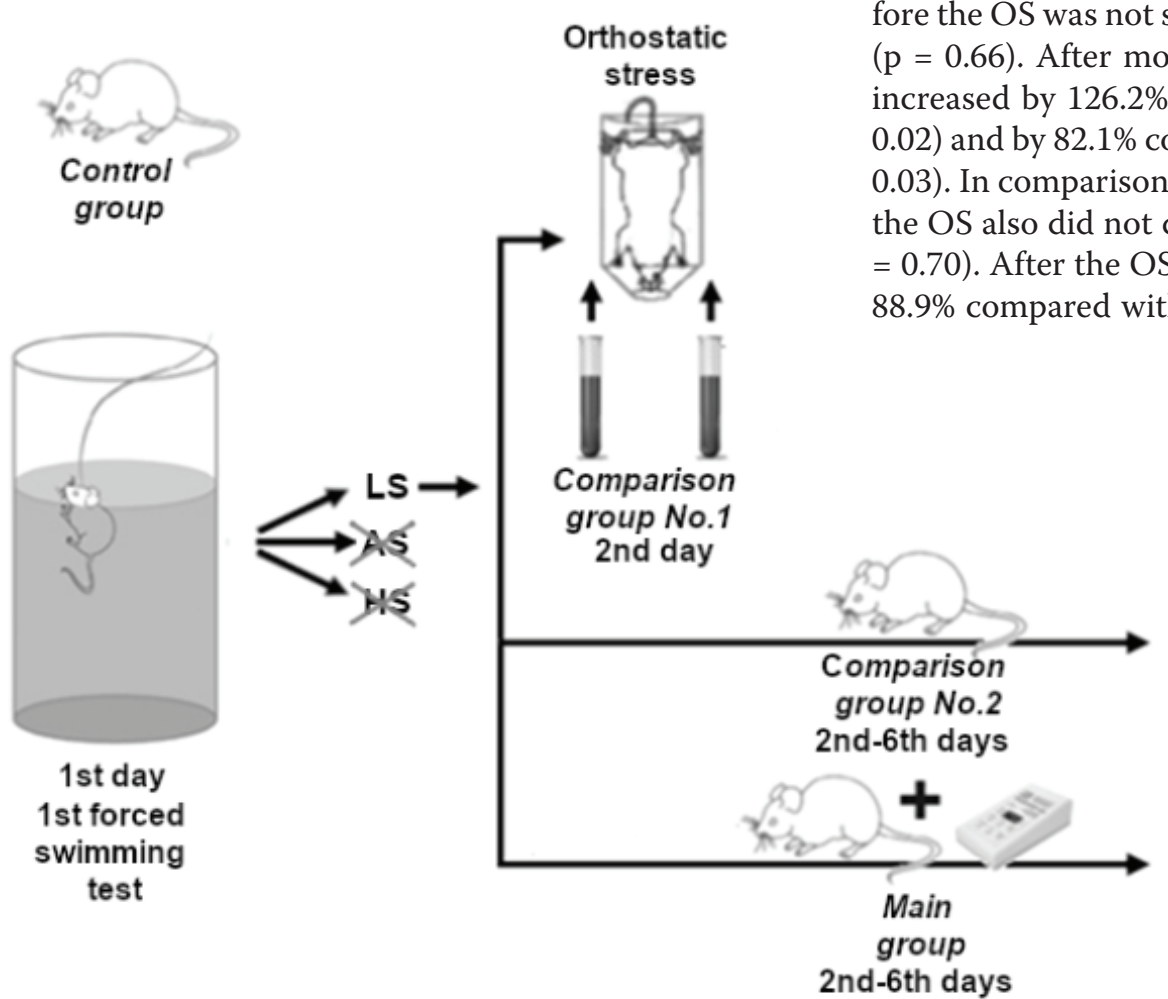

Figure 1. Scheme of the Experiment
(Q1-Q3), where Me is the median, Q1 is the lower and Q3 is the upper quartiles. To evaluate statistically significant differences in paired comparisons of dependent groups, the Wilcoxon test (W-test) was used, and for the intergroup differences between the two independent groups the Mann-Whitney (MW-test) criteria were applied. The critical level of significance (p-value) in the verification of statistical hypotheses was assumed to be 0.05 .

\section{RESULTS}

The results of forced swimming test

Conducting 5 sessions of cathodic tDCS after the 1st FST in rats from the main group leaded to an increase in the swimming time according to the results of the 2nd FST by $47.7 \%$ (W-test, $\mathrm{p}=0.001$ ), whereas there were no significant differences in the comparison group 2 (W-test, $\mathrm{p}$ $=0.05)$ (Table 1$)$.

\section{Dynamics of indices of endocrine and cytokine profile}

The level of adrenaline in the comparison group 1 before the OS was not significantly different from the control $(\mathrm{p}=0.66)$. After modeling the OS the level of adrenaline increased by $126.2 \%$ in comparison with the control $(\mathrm{p}=$ 0.02 ) and by $82.1 \%$ compared to its level before the OS ( $p=$ $0.03)$. In comparison group 2 the level of adrenaline before the OS also did not differ significantly from the control ( $p$ $=0.70)$. After the OS the level of adrenaline was higher by $88.9 \%$ compared with the control $(\mathrm{p}=0.02)$ and by $92.7 \%$

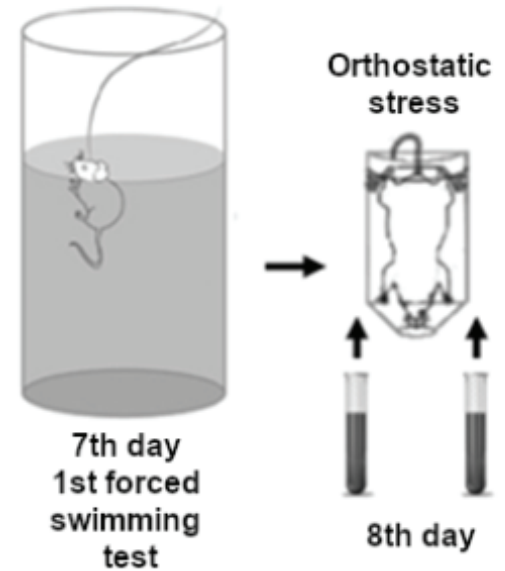




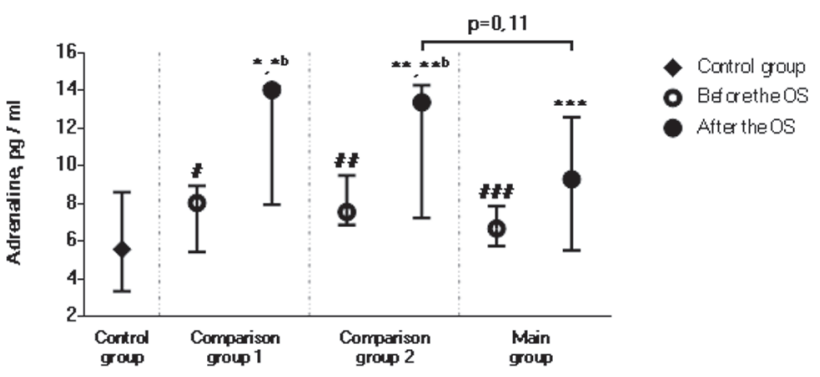

Figure 2. The level of adrenaline in blood plasma of rats

The level of adrenaline in blood plasma in comparison with the control

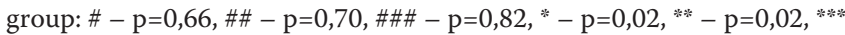
$-p=0,40$; the level of adrenaline in blood plasma in comparison with the level before the OS: ${ }^{* b}-p=0,03,{ }^{* * b}-p=0,04$

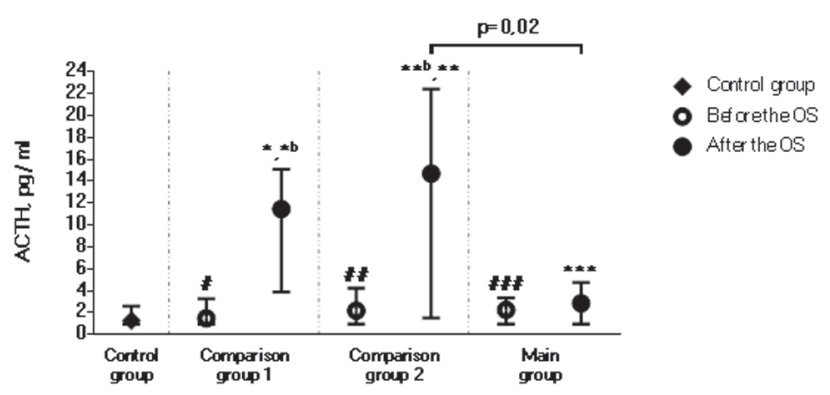

Figure 3. The level of ACTH in blood plasma of rats

The level of ACTH in blood plasma in comparison with the control group: \# - p=0,25, \#\# - p=0,39, \#\# - p=0,82, * $-\mathrm{p}=0,004,{ }^{* *}-\mathrm{p}=0,005$, * $\mathrm{p}=0,46$; the level of ACTH in blood plasma in comparison with the level before the OS: $* \mathrm{~b}-\mathrm{p}=0,008, * \mathrm{*}-\mathrm{p}=0,02$

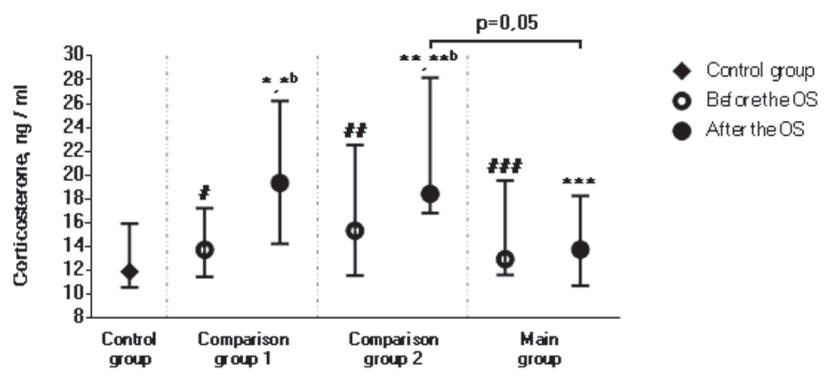

Figure 4. The level of corticosterone in blood plasma of rats

The level of corticosterone in blood plasma in comparison with the control group: $\#-p=0,66$, \#\# - p=0,39, \#\#\#-p=0,59, ${ }^{*}-p=0,02,{ }^{* *}-p=0,02$ **** $-\mathrm{p}=0,46$; the level of corticosterone in blood plasma in comparison with the level before the OS: ${ }^{* b}-p=0,22, * * b-p=0,22$

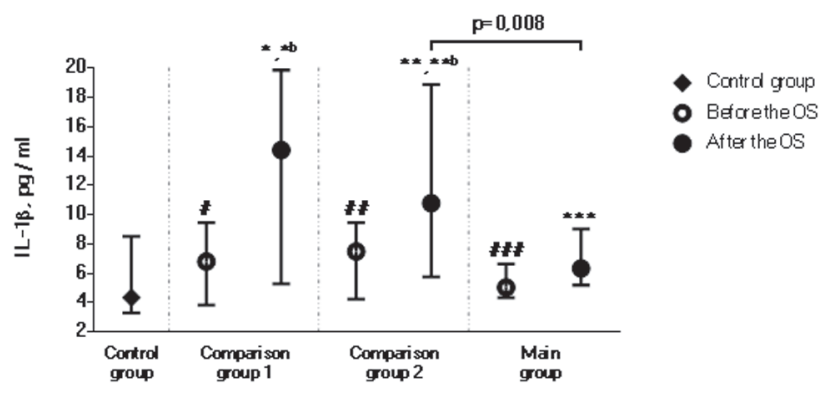

Figure 5. The level of IL-1 $\beta$ in blood plasma of rats

The level of IL-1 $\beta$ in blood plasma in comparison with the control group

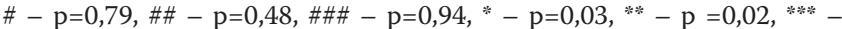
$\mathrm{p}=0,22$; the level of IL- $1 \beta$ in blood plasma in comparison with the level before the OS: ${ }^{* b}-p=0,03,{ }^{* * b}-p=0,02$ compared to its level before the OS $(\mathrm{p}=0.04)$. In the main group, both before and after the OS, there were no reliable differences with the control $(\mathrm{p} \geq 0.05)$. Meanwhile, the adrenaline level in the main group 2 hours after the OS was in 1.4 times lower than in the comparison group 2 (p $=0.11$ ) (Figure 2).

The ACTH level in the comparison group 1 before the OS was not reliably different from the control $(p=0.25)$. After the OS the level of ACTH increased in 12.2 times in comparison with the control $(\mathrm{p}=0.004)$ and in 5 times in comparison with the level before the OS ( $\mathrm{p}=0.008)$. In the comparison group 2 the level of ACTH before the OS was not reliably different from the control $(p=0.39)$. After the OS the level of ACTH was in 10.5 times higher in comparison with the control $(\mathrm{p}=0.005)$ and in 5.5 times higher in comparison with the level before the OS $(p=0.02)$. In the main group of rats both before and after the OS there were no reliable differences with the control $(\mathrm{p} \geq 0.05)$. Meanwhile, the ACTH level 2 hours after the OS in the main group was in 8.2 times lower than in the comparison group $2(\mathrm{p}=0.02)$ (Figure 3$)$.

The level of corticosterone in the comparison group 1 before the OS was not reliably differ from the control ( $\mathrm{p}=$ 0.66). After the OS the level of corticosterone increased by $105.1 \%$ compared with the control $(p=0.02)$. In the comparison group 2 corticosterone before the OS did not differ reliably from control ( $p=0.39$ ). After the OS the level of corticosterone was higher by $70.1 \%$ compared with the control $(\mathrm{p}=0.02)$. In the main group of rats both before and after the OS there were no reliable differences with the control ( $p \geq 0.05$ ). Meanwhile, the corticosterone level in the main group 2 hours after the OS was lower in 1.4 times than in the comparison group $(\mathrm{p}=0.05)$ (Figure 4$)$.

The level of IL-1 $\beta$ in the comparison group 1 before the OS was not reliably differ from the control $(p=0,79)$. After the OS the level of IL- $1 \beta$ increased by $275.7 \%$ in comparison with the control $(\mathrm{p}=0.03)$ and by $136 \%$ compared with the level before the OS ( $p=0.03$ ). In the comparison group 2 the level of IL-1 $\beta$ before the OS was not reliably different from the control $(\mathrm{p}=0.48)$. After the OS the level of IL-1 $\beta$ was higher by $178.2 \%$ compared with the control ( $p$ $=0.02$ ) and by $59 \%$ compared with the level before the OS $(p=0.02)$. In the main group both before and after the OS, there were no reliable differences with the control $(\mathrm{p} \geq 0.05)$. In the main group the level of IL-1 $\beta 2$ hours after the OS was in 1.5 times lower than in the comparison group ( $\mathrm{p}=$ 0.008) (Figure 5).

The level of IL- 6 in the comparison group 1 before the OS was not reliably different from the control $(\mathrm{p}=0,13)$. After the OS the level of IL- 6 increased in 7.2 times in comparison with the control $(\mathrm{p}=0.004)$ and in 3 times in comparison with its level before the OS $(p=0.02)$. In the comparison group 2 the level of IL- 6 before the OS was not reliably different from control $(p=0.10)$. After the OS, the level of IL- 6 was in 6.7 times higher in comparison with the control $(\mathrm{p}=0.005)$ and in 3 times in comparison with the level before the OS ( $p=0.04)$. In the main group both 
before and after the OS there were no reliable differences with the control $(\mathrm{p} \geq 0.05)$. Meanwhile, in the main group the level of IL- 62 hours after the OS was in 2.2 times lower than in the comparison group $(\mathrm{p}=0.05)$ (Figure 6).

Analysis of the IL-10 level in blood plasma revealed no reliable differences in any group of rats $(\mathrm{p} \geq 0.05)$ (Figure 7$)$.

\section{DISCUSSION}

The duration of swimming in the FST largely depends on the timely transition from active behavior (attempts to get out and active scrutiny of the aquarium) to passive one (immobilization on the water surface, saving style of swimming) (17).

According to the review of de Kloet and Molendijk, it is incorrectly, as was done before, to associate an increase in the duration of immobilization (passive coping) in the forced swimming test with depressive-like behavior. Oppositely, the passive coping strategy is associated with an increase in the swimming duration, and, consequently, this behavioral program facilitates to the survival of an animal (5).

Conducting the forced swimming test causes a significant reaction from the SAS and the GPAS, as well as from key neurotransmitter systems of the brain, primarily dopaminergic (18). An intent consideration to the dopaminergic system is due to its role in the pathogenesis of stress and the development of stress-induced diseases such as depression (19). It is the dopaminergic neurotransmission in the limbic brain system that plays a key function in the transition from active to passive behaviors in the forced swimming test $(5,20)$. It is known that the cooperation of $\beta$-endorphin with $\mu$-and $\delta$-opioid receptors stimulates the production of dopamine (11).

Thus, it can be assumed that the increase in the swimming duration in rats receiving cathodic tDCS is due to $\beta$-endorphin-dependent stimulation of the dopaminergic system of the brain stem.

Adrenaline is a hormone that is released in a reaction to stress from the adrenal medulla in the bloodstream and mediates short-term response to stressors initiating a series of behavioral and physiological changes that allow the body to implement a "fight or flight" program (21). The catecholamines effects are mediated by the cooperation with central and peripheral $\alpha$ - and $\beta$-adrenergic receptors. Consequently, the result of increasing the level of circulating catecholamines (adrenaline and noradrenaline) is the activation of metabolism and energy mobilization from the depot, tachycardia, pupillary dilatation, bronchial dilatation, respiration strengthening, peripheral vasospasm and redistribution of circulating blood $(21,22)$. According to the referenses, a high level of catecholamines in blood plasma is associated with aggressive behavior in rats (active-coping strategy) (23). In rats group applied tDCS were not reliable changes in adrenaline concentration compared to the control and the comparison groups. It was explained

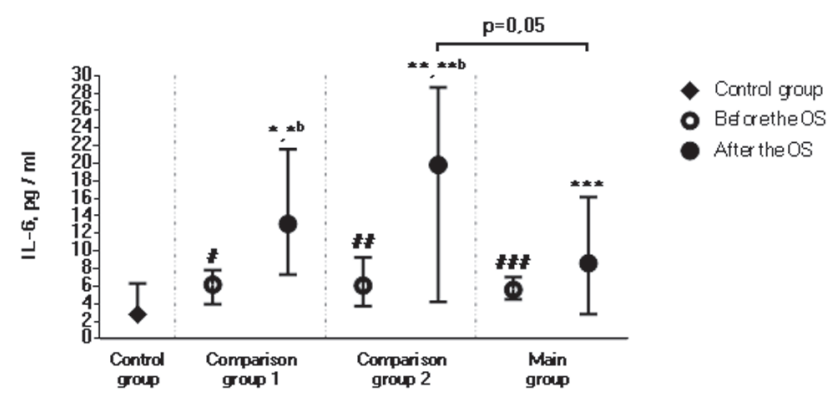

Figure 6. The level of IL-6 in blood plasma of rats The level of IL- 6 in blood plasma in comparison with the control group: \# - p = 0,13, \#\# - p=0,10, \#\# - p=0,18, * - p =0,004, ** $-\mathrm{p}=0,005$, *** $\mathrm{p}=0,10$; the level of IL- 6 in blood plasma in comparison with the level before the OS: ${ }^{* b}-p=0,02, * * b-p=0,04$

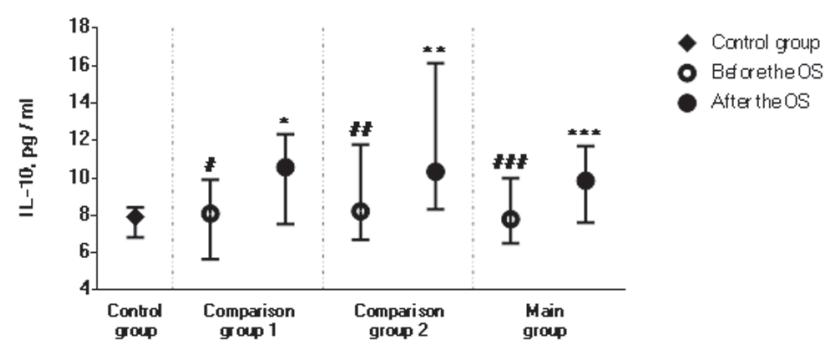

Figure 7. The level of IL-10 in blood plasma of rats

The level of IL-10 in blood plasma in comparison with the control group: $\#-p=0,93$; the level of IL-10 in blood plasma in comparison with the level before the OS: \#\# - p=0,48. in relation to to the comparison group 2 two hours after the OS.\#\#\#-p=0,82, * $-\mathrm{p}=0,13,-\mathrm{p}=0,06,-\mathrm{p}=0,52$

by the fact that blood sampling was carried out 2 hours later the orthostatic stress, and the released adrenaline was largely metabolized (24).

Moreover, according to the data of the references, rats with low swimming duration in the FST are characterized by a hypoactivity of the SAS on the background of a relative preponderance of the activity of the GPAS, which was observed during the comparison of corticosterone and adrenaline concentrations between comparison groups (rats with low stress sustainability and endurance) and the control (rats randomly selected from the general population) $(21,25)$.

The tendency in the main group to reduce adrenaline concentration in 1.4 times in regard to the comparison group also can be explained by the limiting effect of the $\beta$-endorphin entering the systemic circulation on the release of catecholamines (26).

IL- $1 \beta$ is the central mediator of inflammation and takes an important part in the course of autoimmune, inflammatory, infectious and degenerative diseases. IL- $1 \beta$ increases the production of other cytokines involved in the development of inflammation and plays an important role in the depression pathogenesis $(27,28)$. Today there is sufficient evidence that IL-1 $\beta$ plays an important role in neuroendocrine and behavioral reactions in stress. Receptors to IL-1 $\beta$ are found at all levels of the GPAS: hypothalamus, pituitary and adrenal glands. It stimulates the synthesis of glucocorticoids. At the same time high concentrations of glucocorticoids can suppress excessive synthesis of IL-1 $\beta$. However, despite the 
close interaction of the cytokines system and GPAS, a strict correlation between the levels of glucocorticoids and cytokines, in particular IL-1 $\beta$, cannot be established (29). It has been established that the level of IL-1 $\beta$ increases at an acute and a chronic stress, while low (physiological) levels of IL-1 $\beta$ are adaptive. Thus, a blockade of IL- $1 \beta$ signaling can be considered as a method of prevention and treatment of stressassociated mental disorders $(30,31)$.

IL-6 is a pro-inflammatory cytokine, an increase in the level of which accompanies the course of both acute and chronic stress (32). The main functions of IL-6 are an activation of T-lymphocyte proliferation and B-lymphocyte differentiation, a stimulation of leukocyte chemotaxis, an increase of fibroblasts and osteoclasts activity and an activation of the synthesis of acute phase proteins. It also takes part in a transition of acute inflammation to chronic and a control of body weight (33).

IL-6 participates in the modulation of behavior in the FST, mainly facilitating to the reduction of the swimming duration. Meanwhile, its effects are realized through the amygdala or hippocampus due to the activation of the Erk1/2 signaling track (34).

A distinct increase of the IL-6 concentration in blood is noted in anxiety disorders and depression (35). A number of studies show that, although regular physical activity reduces inflammation and production of cytokines, however, intensive exercises facilitate to the production and release of IL- 6 by skeletal muscles. Meanwhile, IL- 6 produced during physical activity inhibits production of TNF- $\alpha$ and induces production of IL-10 $(32,36)$.

IL-10 is an important anti-inflammatory cytokine, whose key function is to protect tissues from damage caused by infectious agents and inflammation, scarring and preventing the development of autoimmune diseases as well (37). The absence of reliable intergroup differences in the plasma concentration of IL-10 supposedly indicates of its secondary role in the development of the OS. According to the references an increase of IL-10 in plasma concentration defers after an increase of pro-inflammatory cytokines (IL-1 $\beta$, IL-6, TNF- $\alpha$ ) in plasma (38). As studies show, at the same time acute stress has no significant effect on the level of IL-10 circulating (39).

In accordance with A.R. Mesquita, during the FST rats knocked out by the IL-10 gene showed an increase in the duration of immobilization, which was neutralized by injection administration of IL-10. In rats with increased IL10 expression changes were opposite knocked-out. Meanwhile, in both cases the found regularity related to the female rats, and in male rats there also was no significant difference in the results of the FST (40).

\section{CONCLUSIONS}

According to the results of the 1st FST, the duration of swimming in rats with low stress sustainability and endurance was less than 184 seconds, and there were no signifi- cant differences with the 2nd FST. The development of the OS in rats with low stress sustainability and endurance is accompanied by an increase in plasma content of adrenaline, of ACTH, of corticosterone, of IL- $1 \beta$, of IL- 6 , of IL10. Based on the results of the 2nd FST, conducting 5 sessions of tDCS in rats with low stress stability increases the swimming duration by $47.7 \%$, and, in this case, the OS is accompanied by a decrease in plasma content the following components: adrenaline, ACTH, corticosterone, IL- $1 \beta$, IL-6, IL-10 towards the comparison group. There were no reliable differences in the IL-10 content between animal groups which indicate its secondary role in pathogenesis of acute stress.

The received data indicate a considerable potential of cathodic tDCS for further studies as a method of increasing stress sustainability and endurance, as well as preventing stress-associated diseases.

\section{REFERENCES}

1. Bains, J.S., Cusulin, J.I.W., \& Inoue, W. (2015). Stressrelated synaptic plasticity in the hypothalamus. Nature Reviews Neuroscience, 16(7), 377-388. DOI:10.1038/ nrn3881

2. Everly Jr, G.S., \& Lating, J.M. (2012). A clinical guide to the treatment of the human stress response (3rd ed.). Springer Science \& Business Media. DOI:10.1007/9781-4614-5538-7

3. Carroll, D., Ginty, A.T., Whittaker, A.C., Lovallo, W.R., \& de Rooij, S.R. (2017). The behavioural, cognitive, and neural corollaries of blunted cardiovascular and cortisol reactions to acute psychological stress. Neuroscience \& Biobehavioral Reviews, 77, 74-86. DOI:10.1016/j.neubiorev.2017.02.025

4. Slavich, G.M., \& Irwin, M.R. (2014). From stress to inflammation and major depressive disorder: a social signal transduction theory of depression. Psychological bulletin, 140(3), 774-815. DOI:10.1037/a0035302

5. De Kloet, E.R., \& Molendijk, M.L. (2016). Coping with the forced swim stressor: towards understanding an adaptive mechanism. Neural Plasticity. DOI:10.1155/2016/6503162

6. Anderson, E.H., \& Shivakumar, G. (2013). Effects of exercise and physical activity on anxiety. Frontiers in psychiatry, 4, 27. DOI:10.3389/fpsyt.2013.00027

7. Valentino, R.J., \& Van Bockstaele, E. (2015). Endogenous opioids: the downside of opposing stress. Neurobiology of stress, 1, 23-32. DOI:10.1016/j.ynstr.2014.09.006

8. Le Merrer, J., Becker, J.A., Befort, K., \& Kieffer, B.L. (2009). Reward processing by the opioid system in the brain. Physiological reviews, 89(4), 1379-1412. DOI:10.1152/physrev.00005.2009

9. Barfield, E.T., Moser, V.A., Hand, A., \& Grisel, J. (2013). $\beta$-endorphin modulates the effect of stress on noveltysuppressed feeding. Frontiers in behavioral neuroscience, 7, 19. DOI:10.3389/fnbeh.2013.00019 
10. Hegadoren, K.M., O’Donnell, T., Lanius, R., Coupland, N.J., \& Lacaze-Masmonteil, N. (2009). The role of $\beta$-endorphin in the pathophysiology of major depression. Neuropeptides, 43(5), 341-353. DOI:10.1016/j. npep.2009.06.004

11. Merenlender-Wagner, A., Dikshtein, Y., \& Yadid, G. (2009). The $\beta$-Endorphin Role in Stress-Related Psychiatric Disorders. Current drug targets, 10(11), 10961108. DOI:10.2174/138945009789735147

12. Trofimenko, A.I., Kade, A.K., Nehaj, F.A., Lebedev, V.P., Levichkin, V.D., \& Zanin, S.A. (2014). Dynamics of level $\beta$-endorphinins at modeling of the ischemic stroke at rats. Kuban Scientific Medical Bulletin, (3), 115-118. DOI:10.25207/1608-6228-2014-3-115-118 (In Russ.)

13. Lebedev, V.P., Savchenko, A.B., Kacnel'son, Ja.S., \& Petrjaevskaja, N.V. (1988). Ob opiatnom mehanizme transkranial'noj jelektroanal'gezii u krys i myshej. Fiziol. zhurn. SSSR, 74(9), 1249-1256. (In Russ.)

14. Karkischenko, V.N., Kapanadze, G.D., Dengina, S.E., \& Stankova, N.V. (2011). Working out of a technique for physical endurance of small laboratory animals for studying of different medicine. Biomedicine, 1(1), 72 74. (In Russ.)

15. Digurova, I.I., \& Gushchin, A.G. (2013). Influence of stress-resistance on hemorheological indices in norm and under orthostatic stress. Yaroslavl Pedagogical Bulletin, 3(1), 107-110. (In Russ.)

16. Lipatova, A.S., Poljakov, P.P., Kade, A.Kh., Zanin, S.A., Trofimenko, A.I., \& Malysheva T.V. (2015). Modification of the procedure TES-therapy for its use in small laboratory rodents. Modern problems of science and education, 5, 347-347. (In Russ.)

17. Molendijk, M.L., \& de Kloet, E.R. (2015). Immobility in the forced swim test is adaptive and does not reflect depression. Psychoneuroendocrinology, 62, 389-391. DOI:10.1016/j.psyneuen.2015.08.028

18. Connor, T.J., Kelly, J.P., \& Leonard, B.E. (1997). Forced swim test-induced neurochemical, endocrine, and immune changes in the rat. Pharmacology Biochemistry and Behavior, 58(4), 961-967. DOI:10.1016/S00913057(97)00028-2

19. Grace, A.A. (2016). Dysregulation of the dopamine system in the pathophysiology of schizophrenia and depression. Nature Reviews Neuroscience, 17(8), 524532. DOI:10.1038/nrn.2016.57

20. Campus, P., Canterini, S., Orsini, C., Fiorenza, M.T., Puglisi-Allegra, S., \& Cabib, S. (2017). Stress-induced reduction of dorsal striatal D2 dopamine receptors prevents retention of a newly acquired adaptive coping strategy. Frontiers in pharmacology, 8, 621. DOI:10.3389/fphar.2017.00621

21. Wong, D.L., Tai, T.C., Wong-Faull, D.C., Claycomb, R., Meloni, E.G., Myers, K.M., Carlezon Jr, W.A., \& Kvetnansky, R. (2012). Epinephrine: A short-and longterm regulator of stress and development of illness. Cellular and molecular neurobiology, 32(5), 737-748. DOI:10.1007/s10571-011-9768-0
22. Lucassen, P.J., Pruessner, J., Sousa, N., Almeida, O.F., Van Dam, A.M., Rajkowska, G., Swaab D.F., \& Czéh, B. (2014). Neuropathology of stress. Acta neuropathologica, 127(1), 109-135. DOI:10.1007/s00401-013-1223-5

23. Koolhaas, J.M., De Boer, S.F., Buwalda, B., \& Van Reenen, K. (2007). Individual variation in coping with stress: a multidimensional approach of ultimate and proximate mechanisms. Brain, behavior and evolution, 70(4), 218-226. DOI:10.1159/000105485

24. Tank, A.W., \& Lee Wong, D. (2015). Peripheral and central effects of circulating catecholamines. Compr Physiol, 5(1), 1-15. DOI:10.1002/cphy.c140007

25. De Miguel, Z., Vegas, O., Garmendia, L., Arregi, A., Beitia, G., \& Azpiroz, A. (2011). Behavioral coping strategies in response to social stress are associated with distinct neuroendocrine, monoaminergic and immune response profiles in mice. Behavioural brain research, 225(2), 554-561. DOI:10.1016/j. bbr.2011.08.011

26. Cozzolino, D., Sasso, F. C., Salvatore, T., Torella, M., Cittadini, A., Gentile, S., Torella R., \& Giugliano, D. (2004). Acute effects of $\beta$-endorphin on cardiovascular function in patients with mild to moderate chronic heart failure. American heart journal, 148(3), 530. DOI:10.1016/j.ahj.2004.01.029

27. Bujak, M., \& Frangogiannis, N.G. (2009). The role of IL-1 in the pathogenesis of heart disease. Archivum immunologiae et therapiae experimentalis, 57(3), 165176. DOI:10.1007/s00005-009-0024-y

28. Goshen, I., Kreisel, T., Ben-Menachem-Zidon, O., Licht, T., Weidenfeld, J., Ben-Hur, T., \& Yirmiya, R. (2008). Brain interleukin-1 mediates chronic stressinduced depression in mice via adrenocortical activation and hippocampal neurogenesis suppression. Molecular psychiatry, 13(7), 717-728. DOI:10.1038/ sj.mp. 4002055

29. Hueston, C.M., \& Deak, T. (2014). The inflamed axis: the interaction between stress, hormones, and the expression of inflammatory-related genes within key structures comprising the hypothalamic-pituitary-adrenal axis. Physiology \& behavior, 124, 77-91. DOI:10.1016/j.physbeh.2013.10.035

30. Koo, J.W., \& Duman, R.S. (2009). Evidence for IL-1 receptor blockade as a therapeutic strategy for the treatment of depression. Current opinion in investigational drugs (London, England: 2000), 10(7), 664-671

31. Leonard, B., \& Maes, M. (2012). Mechanistic explanations how cell-mediated immune activation, inflammation and oxidative and nitrosative stress pathways and their sequels and concomitants play a role in the pathophysiology of unipolar depression. Neuroscience \& Biobehavioral Reviews, 36(2), 764-785. DOI:10.1016/j. neubiorev.2011.12.005

32. Rohleder, N., Aringer, M., \& Boentert, M. (2012). Role of interleukin- 6 in stress, sleep, and fatigue. Annals of the New York Academy of Sciences, 1261(1), 88-96. DOI:10.1111/j.1749-6632.2012.06634.x 
33. Hunter, C.A., \& Jones, S.A. (2015). IL-6 as a keystone cytokine in health and disease. Nature immunology, 16(5), 448-457. DOI:10.1038/ni.3153

34. Wu, T.H., \& Lin, C.H. (2008). IL-6 mediated alterations on immobile behavior of rats in the forced swim test via ERK1/2 activation in specific brain regions. Behavioural brain research, 193(2), 183-191. DOI:10.1016/j.bbr.2008.05.009

35. O’Donovan, A., Hughes, B.M., Slavich, G.M., Lynch, L., Cronin, M.T., O'Farrelly, C., \& Malone, K. M. (2010). Clinical anxiety, cortisol and interleukin-6: Evidence for specificity in emotion-biology relationships. Brain, behavior, and immunity, 24(7), 1074-1077. DOI:10.1016/j.bbi.2010.03.003

36. Kiecolt-Glaser, J.K., Gouin, J.P., \& Hantsoo, L. (2010). Close relationships, inflammation, and health. Neuroscience \& Biobehavioral Reviews, 35(1), 33-38. DOI:10.1016/j.neubiorev.2009.09.003

37. Ouyang, W., Rutz, S., Crellin, N.K., Valdez, P.A., \& Hymowitz, S.G. (2011). Regulation and functions of the IL-10 family of cytokines in inflammation and disease. Annual review of immunology, 29, 71-109. DOI:10.1146/annurev-immunol-031210-101312

38. Iyer, S.S., \& Cheng, G. (2012). Role of interleukin 10 transcriptional regulation in inflammation and autoimmune disease. Critical Reviews ${ }^{\mathrm{Tm}}$ in Immunology, 32(1). DOI:10.1615/CritRevImmunol.v32.i1.30

39. Voorhees, J.L., Tarr, A.J., Wohleb, E.S., Godbout, J.P., Mo, X., Sheridan, J.F., Eubank, T.D., \& Marsh, C.B. (2013). Prolonged restraint stress increases IL-6, reduces IL-10, and causes persistent depressive-like behavior that is reversed by recombinant IL-10. PloS one, 8(3), e58488. DOI:10.1371/journal.pone.0058488

40. Mesquita, A.R., Correia-Neves, M., Roque, S., Castro, A. G., Vieira, P., Pedrosa, J., Palha, J.A., \& Sousa, N. (2008). IL-10 modulates depressive-like behavior. Journal of psychiatric research, 43(2), 89-97. DOI:10.1016/j. jpsychires.2008.02.004 